\title{
THE DETERMINANTS OF CORPORATE DEBT RATIOS IN CHOSEN EUROPEAN COUNTRIES
}

\author{
Karolina Daszynska-Zygadlo ${ }^{1}$, Aleksandra Szpulak ${ }^{2}$ \\ ${ }^{1}$ Wroclaw University of Economics, Poland, karolina.zygadlo@ue.wroc.pl \\ ${ }^{2}$ Wroclaw University of Economics, Poland, aleksandra.szpulak@ue.wroc.pl \\ cross ${ }^{\text {ref }} \mathrm{http} / / / \mathrm{dx}$.doi.org/10.5755/j01.em.17.1.2252
}

\begin{abstract}
The capital structure theories assume that level of debt is determined by company's value, expected cash sources and profitability. The goal of this paper is to analyze determinants of corporate debt ratios. The main focus was put on analyzing whether the differences of willingness to use debt by companies result from profitability and/or collateral value of assets and/or company's size. The analysis of public companies from France, Germany, United Kingdom and the Netherlands, from non-financial sectors, in years 2003-2010 was carried out. No evidence for positive connection association between debt level and profitability was found. We observed reverse relationship, however we cannot treat this as a general rule. We also cannot claim there is any particular corporate debt level specific because of country or sector, however the company's size seems to be important determinant of debt usage.

Keywords: corporate debt ratio, capital structure, panel data regression analysis.

JEL classification: G17, G32.
\end{abstract}

\section{Corporate debt determinants - theory and research overview}

According to the capital structure theory a certain level of debt can be achieved to maximize company's value. According to the traditional trade-off theory companies may reach an optimal capital structure by trading off the benefits and costs of taking up more debt. More debt means more tax advantages for the company, but also such situation may be used to mitigate the agency problem between managers and shareholders because it can reduce the cash flow under the control of the managers (Jensen 1986).

There are several issues regarding the debt level determinants that are present in the literature, among which main focus is put on: (1) how to estimate target level of debt - what criteria to take (Donaldson 1961, Myers 1984); (2) what factors determine tendencies of companies to use debt financing (Remmers, Stonehill, Wright, Beekhuisen 1974; Titman, Wessels 1988; Morellec 2000; Gaud, Hoesli, Bender 2005; DeAngelo, DeAngelo 2007; Giambona, Schwienbacher 2008; Yanga, Leeb, Gu, Leed 2010).

There were many research conducted examining the factors influencing capital structure choice of companies and its relevance to capital structure theories. According to the period of time examined, choice of the method and the sample the results achieved differ. That is why this issue remains disputable and interesting for further research. In most cases the most important factors corporate debt levels are: profitability, collateral value of assets, company's size, opportunities of growth and uniqueness.

Due to the existence of costs discussed by Myers and Majluf (Myers 1984; Myers, Majluf 1984) that arise from asymmetric information or transaction costs, the past profitability and amount of earnings that could be retained should have important influence on current capital structure of companies. According to most of capital structure theories the type of assets owned by a company in some way affects its capital structure choice. A positive relation between debt ratios and the capacity of companies to collateralize their debt may exist due to the fact that if assets are less collateralizable creditors may require more favorable terms, which in turn may lead to equity financing rather that debt financing (Titman, Wessels 1988). The fact that large firms tend to be more diversified and therefore less prone to bankruptcy, may suggest that large firms should be more highly leveraged (Frank, Goyal 2003; Lemmon, Zender 2001; Şenay, Mozumdar 2004). But from the perspective of costs of issuing debt and equity it could be stated that small firms pay much more to issue new equity than the large ones, which could suggest that small firms may use debt financing to higher extend. On the other hand smaller companies may be less affective by agency cost that makes them more profitable and better gearing adjusted (Lasfer 1999).

On the basis of literature overview the hypotheses of the paper are stated as:

(1) given country and sector there exists association between corporate debt level and profitability

(2) given country and sector there exists association between corporate debt level and collateral value of assets

(3) given country and sector there exists association between corporate debt level and company's size. 
Additionally from theoretical point of view companies from the same sector should have similar capital structure according to chosen financing policy and should show similar willingness to use debt financing according to tax and legal conditions of running a business in a certain country.

\section{Research results}

\section{Data and methodology}

To test previously pointed hypotheses panel data regression analysis was employed. Representative sample of public companies from France, Germany, United Kingdom and the Netherlands, from nonfinancial sectors, in years 2003-2010 was chosen. Bearing in mind that the research period covers years of crisis on financial markets that influenced economy and business, special attention was given to the results obtained in this particular period. To create relevant homogenous groups of companies ANOVA analysis was employed. According to the results obtained from ANOVA all data was divided by country of origin, sector and year. Corporate debt ratios was measured by long term debt, short term debt and total debt over total book assets value ratio, respectively. Corporate debt is measured on the basis of book values, assuming that book values of debt and equity were less sensitive to financial distress that companies were facing during the years of crisis on the financial markets. Profitability was measured by operational income over sales ratio, return on assets and return on equity, collateral value of assets was measured by fixed assets over total assets ratio while company's size by logarithm of sales. Data was gathered form Amadeus database and all calculations were conducted in STATISTICA software. Results revile that distributions of debt measures are skewed to the right for long and short term debt ratios, while it can be approximated by normal distribution for total debt ratio. Not all factors (i.e. country, sector and year) where statistically significant and therefore it was reasonable to concentrate on panels build from countries and years. Moreover, raw data gained from the database contained several mistakes like negative values of debt ratios or highly negative values of operational income over sales ratio.

\section{Debt measures distributions}

The goal of statistical analysis was the identification of the dependent variable. Three candidates were considered: long term debt, short term debt and total debt over total book assets value ratio, respectively. The proprieties of distribution desired for further analysis were: symmetric and mound shape distribution defined by normal distribution. The investigation of the three ratios' distributions was conducted for following groups:

(1) all observations

(2) 4 groups - countries: France, Germany, United Kingdom and the Netherlands

(3) 2 groups - sectors: production and nonproduction

(4) 8 groups - years: form 2003 to 2010

The distribution of long term debt over total book assets value ratio (LD/BTA) is highly skewed to the right for all observations as well as for all countries, in each sector and year. In all cases mean is greater than median and skewness almost always is near 1.5. In this case almost 53\% of all companies had LD/BTA ratio not higher than $10 \%$ of total book assets value while $75 \%$ of all companies had LD/BTA ratio not higher than $20 \%$ of total book assets value.

The distribution of the short term debt over total book assets value ratio (STD/BTA) ratio is skewed to the right as well but skewness is not as strong as it is in case of LD/BTA ratio. Although mean for all analysed groups is greater than median skewness in the same time is lower by around 1 and ranges between 0.3 - 0.9. At the same time STD/BTA ratio distribution is platykurtic while LTD/BTA ratio distribution is leptokurtic what results in higher dispersion of STD/BTA ratio values comparing to LD/BTA ratio. Moreover for two countries: France and Netherlands STD/BTA ratio can be approximated by normal distribution. $75 \%$ of all companies had STD/BTA not higher than $40 \%$ of total book assets value.

In case of total debt over total book assets value ratio (TD/BTA) we observe less homogeneity in the shapes of ratio distributions which is a result of overlapping of previous two ratios' distribution shapes. However, the skewness of TD/BTA distribution for all groups analysed is around 0 what indicates that TD/BTA ratio distribution is more symmetric than previous two ratios' i.e. LD/BTA and STD/BTA distributions. From this general tendency we observe one exception - France where TD/BTA ratio distribution should be recognised as skewed to the left with the highest values of TD/BTA ratio. Kurtosis, as the second indicator of the distribution shape, is negative for all groups but its values are not greater than 0.8 what gives weekly platykurtic distribution of TD/BTA ratio. From all distributions the one - for production companies - may be approximated by normal distribution, what means that companies with high 
LD/BTA ratios have low STD/BTA ratio and vice versa and in 50\% of all production companies TD/BTA ratio ranges between $30-50 \%$ of total book assets value with just a few having very low and very high TD/BTA ratio. For the rest of the groups analysed platykurtic shape of TD/BTA ratio distribution exist due to fact that frequency of low values of TD/BTA ratio is greater than high values of TD/BTA ratio. Usually TD/BTA ratio ranges between $30-60 \%$ of total book assets value. As being the most similar to normal distribution for further analysis TD/BTA ratio was chosen.

\section{ANOVA results}

ANOVA analysis was employed to create homogenous groups of TD/BTA ratio - i.e. groups of companies with similar level and variation of TD/BTA ratio. First - with usage of single factor ANOVA three factors were investigated:

(1) Factor Country with 4 levels: France, Germany, United Kingdom and the Netherlands

(2) Factor Sector with 2 levels: production and nonproduction

(3) Factor Year with 8 levels: 2003 to 2010

The results of single factor ANOVA are given in table 1 .

Table 1. Single factor ANOVA results for TD/BTA ratio

\begin{tabular}{|c|c|c|c|r|c|}
\hline Factor & SS & df & MS & F & p-value \\
\hline Country & 2,545 & 3 & 0,848 & 35,901 & 0,000 \\
\hline Sector & 0,213 & 1 & 0,213 & 9,001 & 0,003 \\
\hline Year & 0,528 & 7 & 0,075 & 3,193 & 0,002 \\
\hline
\end{tabular}

As p-values are less than 0.05 all factors are statistically significant what means that at least one group mean created by each factor is statistically different from others. To create homogenous groups for factor

Country a multiple comparisons of means procedure was employed. Results are given in table 2.

Table 2. Multiple comparison of means results, Scheffe test, factor Country, TD/BTA ratio

\begin{tabular}{|c|c|c|c|c|}
\hline \multirow{2}{*}{ Country } & \multirow{2}{*}{ Mean } & \multicolumn{3}{|c|}{ homogenous group no. } \\
\cline { 3 - 5 } & & $\mathbf{1}$ & $\mathbf{2}$ & $\mathbf{3}$ \\
\hline GERMANY & 0,378 & & $* * * *$ & \\
\hline $\begin{array}{c}\text { UNITED } \\
\text { KINGDOM }\end{array}$ & 0,416 & $* * * *$ & & \\
\hline NETHERLANDS & 0,423 & $* * * *$ & & \\
\hline FRANCE & 0,502 & & & $* * * *$ \\
\hline
\end{tabular}

Next step was to investigate interactions between factors: Country, Sector and Year. For this goal a factorial ANOVA was conducted. The results are given in table 3.

Table 3. Factorial ANOVA results for TD/BTA ratio

\begin{tabular}{|l|c|c|c|c|c|}
\hline Effect & SS & df & MS & F & p-value \\
\hline Country*sector & 0.101 & 3 & 0.034 & 1.420 & 0.235 \\
\hline Country*year & 1.172 & 21 & 0.056 & 2.362 & 0.000 \\
\hline sector*year & 0.013 & 7 & 0.002 & 0.076 & 0.999 \\
\hline Country*sector*year & 0.176 & 21 & 0.008 & 0.354 & 0.997 \\
\hline
\end{tabular}

Only two factors: Country and Year interact (p-value is almost 0.00) what means that general tendency observed in figure 1 may vary from country to country. This can be seen from the mean plot (see figure 1) of TD/BTA ratio grouped simultaneously by factors Country and Year. 
Country ${ }^{*}$ year; Unweighted Means

Current effect: $F(21,14689)=1,2751, p=, 17859$

Effective hypothesis decomposition

Vertical bars denote 0,95 confidence intervals

Include condition: $v 7>=0$

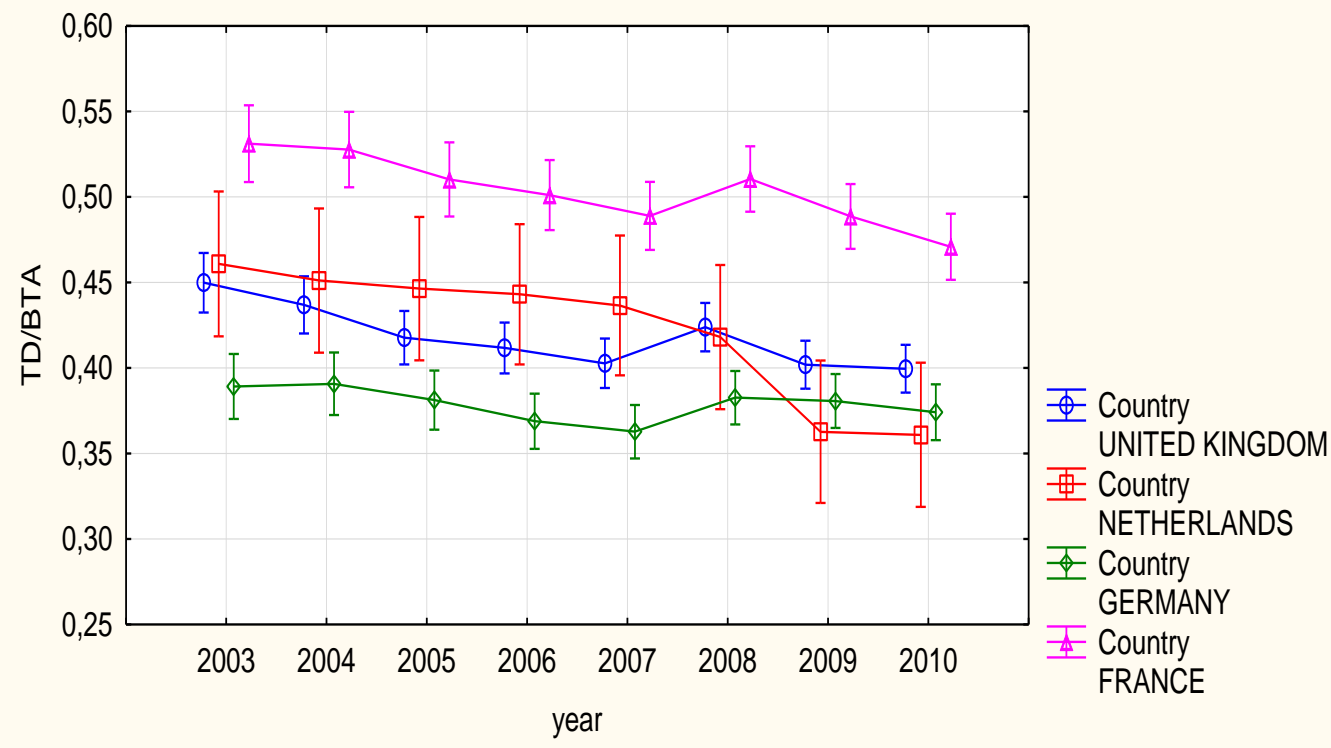

Figure 1. Mean plot for TD/BTA ratio grouped by factors Country and Year

Common tendency, described earlier, is observed in France and in UK. In Netherlands, however, TD/BTA ratio decreases over whole period $2003-2010$ and drops significantly after 2008. In Germany, by contrast, TD/BTA ratio decreases slightly to 2007 and increases after 2007.

\section{Panel data regression analysis}

On the basis of ANOVA results panels for final regression analysis cover groups of TD/BTA ratios created by Country*Year factors:

Panel 1: France and UK over 2003 - 2010;

Panel 2: Netherlands over 2003 - 2010;

Panel 3: Germany over 2003 - 2010;

H1: given country there exists association between corporate debt level and profitability;

$\mathrm{H} 2$ : given country there exists association between corporate debt level and collateral value of assets;

H3: given country there exists association between corporate debt level and company's size.

The variability of TD/BTA ratio $(\mathrm{Y})$ is assumed to be dependent from at least three factors: profitability, collateral value of equity and company's size. Profitability was measured by operational income over sales ratio OI/S (X1), return on assets EBITDA/TA (X2) and return on equity EBIT/E (X3), collateral value of assets was measured by fixed assets over total assets ratio FA/TA (X4) while company's size by logarithm of sales LnS (X5). Because of time series pattern observed in TD/BTA ratio, and not observed in the same time in any explanatory variable $\mathrm{X}$, additional $t$ explanatory variable was included in regression analysis. Hypothesized multiple regression model structure is following:

$$
Y_{i, p}=\alpha_{0, p}+\alpha_{k, p} X_{k, i, p}+t+\varepsilon_{p}
$$

where:

$Y-\mathrm{TD} / \mathrm{BTA}$ ratio

$X_{k}-k$ explanatory variable

$\alpha$ - multiple regression parameters

$\varepsilon$ - error term

$p$ - panel number, $p=1.2 .3$

$k$ - explanatory variable $X$ number, $k=1, \ldots, 5$

$t$-period number, $t=1, \ldots, 8$

$i$ - case number, $i=1, \ldots, 19976$ 
Although first attempt in explaining TD/BTA variability resulted in statistically significant regression coefficients the investigation of correlograms graphing correlations between TD/BTA and explanatory variables visibly excluded existence of such relationships among variables. The results obtained are highly influenced by outliers and influential observations. Some of them exist due to errors, like e.g. negative TD/BTA values. Table 4 consists of basic statistics of explanatory variables including Grubbs tests for detecting unusual observations.

Table 4. Descriptive statistics and Grubbs test for explanatory variables

\begin{tabular}{|l|c|c|c|c|c|c|c|}
\hline $\begin{array}{c}\text { Explanatory } \\
\text { variables }\end{array}$ & Valid N & Mean & $\begin{array}{c}\text { Percentile } \\
\mathbf{5}\end{array}$ & $\begin{array}{c}\text { Percentile } \\
\mathbf{9 5}\end{array}$ & $\begin{array}{c}\text { Std. } \\
\text { Dev. }\end{array}$ & $\begin{array}{c}\text { Grubbs } \\
\text { statistics }\end{array}$ & p-value \\
\hline OI/S & 9603 & 0.302 & 0.079 & 0.913 & 4.733 & 61.676 & 0.000 \\
\hline EBITDA/TA & 14952 & 0.083 & -0.263 & 0.267 & 3.120 & 121.897 & 0.000 \\
\hline EBIT/E & 16113 & 0.061 & -0.696 & 0.534 & 10.118 & 120.063 & 0.000 \\
\hline FA/TA & 16311 & 0.478 & 0.045 & 0.927 & 0.266 & 1.962 & 1.000 \\
\hline LnS & 15280 & 11.002 & 6.073 & 15.745 & 2.862 & 5.535 & 0.000 \\
\hline
\end{tabular}

At least one outlier exists in variables OI/S, EBITDA/TA, EBIT/E and LnS. For these variables 5\% of observations from both sides of distributions were excluded from further analysis. EBITDA/TA was also excluded from further analysis due to strong correlation with EBIT/E which results in multicollinearity of these variables (usually the direction of coefficient before EBITDA/TA in regression model was different from corresponding correlation coefficient). Again multiple regression analysis, particulary a stepwise procedure was employed to estimate regression coefficients (see tab. 5)

Table 5. Regression statistics and regression parameters (data set reduced)

\begin{tabular}{|c|c|c|c|c|}
\hline $\begin{array}{l}\text { explanatory } \\
\text { variables }\end{array}$ & b & Std.Err. of $b$ & $\mathbf{t}(\mathbf{7 3 8 9})$ & p-value \\
\hline Panel 1 & \multicolumn{4}{|c|}{$\mathrm{R}=.375 \mathrm{R} 2=.141$ Adjusted $\mathrm{R} 2=.140 \mathrm{~F}(4.5549)=226.86 \mathrm{p}<0.00$ Std.Error of estimate: .167} \\
\hline Intercept & 0.268 & 0.016 & 16.979 & 0.000 \\
\hline $\mathrm{OI} / \mathrm{S}$ & -0.107 & 0.011 & -9.533 & 0.000 \\
\hline EBIT/E & 0.115 & 0.013 & 8.488 & 0.000 \\
\hline FA/TA & -0.091 & 0.010 & -9.437 & 0.000 \\
\hline $\mathrm{LnS}$ & 0.023 & 0.001 & 17.620 & 0.000 \\
\hline Panel 2 & \multicolumn{4}{|c|}{$\mathrm{R}=.660 \mathrm{R} 2=.435$ Adjusted $\mathrm{R} 2=.423 \mathrm{~F}(2.94)=36.231 \mathrm{p}<.00$ Std.Error of estimate: .123} \\
\hline Intercept & -0.011 & 0.102 & -0.105 & 0.917 \\
\hline $\mathrm{OI} / \mathrm{S}$ & -0.375 & 0.076 & -4.961 & 0.000 \\
\hline $\mathrm{LnS}$ & 0.042 & 0.007 & 5.853 & 0.000 \\
\hline Panel 3 & \multicolumn{4}{|c|}{$\mathrm{R}=.446 \mathrm{R} 2=.199$ Adjusted $\mathrm{R} 2=.196 \mathrm{~F}(3.782)=64.851 \mathrm{p}<0.00$ Std.Error of estimate: .162} \\
\hline Intercept & 0.123 & 0.047 & 2.609 & 0.009 \\
\hline $\mathrm{OI} / \mathrm{S}$ & -0.260 & 0.036 & -7.255 & 0.000 \\
\hline FA/TA & 0.151 & 0.031 & 4.860 & 0.000 \\
\hline $\mathrm{LnS}$ & 0.024 & 0.004 & 6.912 & 0.000 \\
\hline
\end{tabular}

We cannot be fully satisfied with achieved results. Although explanatory variables are statistically significant what means that they may determine TD/BTA ratio, determination coefficient $\mathrm{R}^{2}$ is low. In case of panel 2, sample of non-financial, public companies from the Netherlands, chosen explanatory variables explain $44 \%$ of the real variability of the TD/BTA ratio. It might result from higher homogeneity of this panel than the other two panels. Negative relation between OI/S and TD/BTA ratios can be observed, what means that companies with higher operating margin are less leveraged. On the other hand positive relation can be observed between LnS and TD/BTA ratios what means that bigger companies are more leveraged. 
To support previous conclusion correlation analysis between TD/BTA and explanatory variables $\mathrm{X}$ was carried out. Correlation coefficients between TD/BTA and explanatory variables X are given in table 6 .

Table 6. Correlation coefficients between TD/BTA

and explanatory variables $\mathrm{X}$ in respective panels

\begin{tabular}{|l|c|c|c|}
\hline \multirow{2}{*}{ explanatory variable } & \multicolumn{3}{|c|}{ dependent variable TD/BTA } \\
\cline { 2 - 4 } & panel1 & panel 2 & panel 3 \\
\hline OI/S & -0.19 & -0.48 & -0.32 \\
\hline EBITDA/TA & 0.04 & 0.16 & -0.01 \\
\hline EBIT/E & 0.22 & 0.39 & 0.14 \\
\hline FA/TA & -0.14 & -0.07 & 0.24 \\
\hline LnS & 0.30 & 0.54 & 0.35 \\
\hline
\end{tabular}

Regression coefficients and correlation coefficients have the same direction so there is no coincidence between results of regression and correlation analysis.

Although regression statistics indicate that relationships observed in the sample are statistically significant explained variation of TD/BTA is still very low and ranges from $14 \%$ in the first panel to $42 \%$ in the second panel. So in fact pointed explanatory variable explain some of the variation of TD/BTA but the vast majority of it is not explained at all. This fact appears probably due to heterogeneity of panels and apparent time tendency in TD/BTA that does not exist in explanatory variables and due to some other, not included, factors that influence the TD/BTA.

Correlations coefficients are statistically significant but even though some extreme observations were excluded from analysis investigation of correlograms do not give strong evidence to support observed relationships among variables therefore it direction should be interpret with high distrust.

Explored data set contains several mistakes that may result in existence of unusual observations that influence received regression models. Although some steps were taken in order to exclude such observations but in reality after such a procedure new outliers usually appear.

\section{Conclusions}

The research shows deep diversity of capital choices realized by analyzed companies. We cannot be sure about universal financing policy in researched group however some statistically significant relations have been found. While our results are not conclusive, they document some empirical regularities that are consistent with existing theory.

On the basis of conducted research it can be stated that there exists sufficient evidence to conclude that there is negative association between corporate debt ratio and operational margin ratio. Especially it can be observed in Dutch companies. The higher operating margin the lower debt ratio, which can signify that companies are more likely to finance its operations by internal funds (retained earnings) when availability of that source is increasing. The same relation can be observed in remaining panels, but the relation is weaker. That conclusion is consistent with the results reported by Yanga and coauthors (Yanga, Leeb, Gu, Leed 2010), and Myers and Majluf (Myers 1984; Myers, Majluf 1984) confirming "pecking order theory" to some extent.

There is also association between collateral value of assets (FA/TA) and corporate debt ratio. At least it was found in two out of three analyzed panels. According to existing theory the relation should be positive due to the fact that the higher value of assets that can be used as collateral the higher possibilities of debt financing. Weak positive association exists in companies from France and UK that are represented in panel 1. But negative association exists in panel 3 representing German companies. It proves that results are inconsistent among the whole data set. Weak relationships along with inconsistent results caused rejecting second hypothesis, but it stays in line with result obtained by Titman and Wessels (Titman, Wessels 1988).

Results shown on association of size of companies given as LnS with corporate debt ratio can be treated as sufficient to conclude that size of the company can determine usage of debt. The relation is positive therefore along with growth of the company, increase of debt ratio can be observed. Especially in companies from the Netherlands where there is highest significance, but companies from remaining panels 
show the same tendency. Those results are consistent with these obtained by Yanga and coauthors (Yanga, Leeb, Gu, Leed 2010).

We assume that obtained results may be under considerable influence of lately capital market dynamic changes. Global economic crisis and higher debt restrictions might change financing policy of analyzed companies. Also dividing the data set into more homogenous groups could probably positively influence the explanatory power of conducted research.

\section{References}

1. Chau-Chen Yanga, Cheng-few Leeb, Yan-Xiang Gu, Yen-Wen Leed (2010). Co-determination of capital structure and stock returns-A LISREL approach. An empirical test of Taiwan stock markets, "The Quarterly Review of Economics and Finance", no 50.

2. DeAngelo H, DeAngelo L. (2007). Capital Structure, Payout Policy, and Financial Flexibility, Marshall School of Business Working Paper No. FBE 02-06.

3. Donaldson G. (1961). Corporate Debt Capacity: A Study of Corporate Debt Policy and the Determination of Corporate Debt Capacity, President and Fellows of Harvard College, reprinted 2000 by Beard Books, Washington, D.C.

4. Frank M., Goyal V. (2003). Testing the pecking order theory of capital structure, Journal of Financial Economics, vol. 67.

5. Gaud P., Hoesli M., Bender A. (2005). Debt-Equity Choice in Europe, University of Geneva, FAME - International Center for Financial Asset Management and Engineering, Research Paper 152.

6. Giambona E., Schwienbacher A. (2008). Debt Capacity of Tangible Assets: What is Collateralizable in the Debt Market?, School of Economics and Management, Free University of Bolzano, Italy.

7. Jensen, M.C. (1986). Agency Costs of Free Cash Flow, Corporate Finance and Takeovers, American Economic Review 76.

8. Lasfer, M. A. (1999). Debt structure, agency costs and firm's size An empirical investigation, City University Business School, UK.

9. Lemmon M., Zender J. (2010). Debt Capacity and Tests of Capital Structure Theories, Journal of Financial and Quantitative Analysis, vol. 45

10. Morellec E. (2000). Asset liquidity, capital structure, and secured debt, Journal of Financial Economics, vol. 61.

11. Myers S.C. (1984). The Capital Structure Puzzle, The Journal of Finance, Vol. 39, No. 3

12. Myers S.C., Majluf N. (1984). Corporate financing and investment decisions when firms have information that investors do not have, Journal of Financial Economics, vol. 13.

13. Remmers L., Stonehill A., Wright R., Beekhuisen T. (1974). Industry and Size as Debt Ratio Determinants in Manufacturing Internationally, "Financial Management", vol. 3, no 2.

14. Şenay A., Mozumdar A. (2004). Firm Size, Debt Capacity, and the Pecking Order of Financing Choices, School of Business and Public Administration, George Washington University.

15. Titman S., Wessels R. (1988). The determinants of capital structure choice, "The Journal of Finance", vol. 43, no 1. 